\begin{tabular}{|l|l|l||}
\hline \multicolumn{2}{|c|}{ PublisherInfo } \\
\hline \hline PublisherName & $:$ & BioMed Central \\
\hline \hline PublisherLocation & $:$ & London \\
\hline \hline PublisherImprintName & $:$ & BioMed Central \\
\hline \hline
\end{tabular}

\title{
A classy RNA switch
}

\begin{tabular}{|l|l|l||}
\hline \multicolumn{2}{|c|}{ ArticleInfo } \\
\hline \hline ArticleID & $:$ & 3683 \\
\hline \hline ArticleDOI & $:$ & $10.1186 /$ gb-spotlight-20000516-01 \\
\hline \hline ArticleCitationID & $:$ & spotlight-20000516-01 \\
\hline \hline ArticleSequenceNumber & $:$ & 120 \\
\hline \hline ArticleCategory & $:$ & Research news \\
\hline \hline ArticleFirstPage & $:$ & 1 \\
\hline \hline ArticleLastPage & $:$ & 2 \\
\hline \hline & & RegistrationDate : 2000-05-16 \\
ArticleHistory & $:$ & OnlineDate \\
\hline \hline ArticleCopyright & $:$ & BioMed Central Ltd2000-05-16 \\
\hline \hline ArticleGrants & $:$ & \\
\hline \hline ArticleContext & $:$ & 130591111 \\
\hline \hline
\end{tabular}


In the 12 May Science, Tracy et al. find that an RNA-DNA hybrid is essential for switching from one antibody class to another (for example, IgM to IgG; Science 2000, 288: 1058-1061). The RNA portion of the hybrid is produced from intronic promoters located upstream of each alternative heavy chain constant region. Cytokines determine which intronic promoter is activated. Tracy et al. detect the RNA that remains associated with the transcribed DNA and show, using mice transgenic for RNAse $\mathrm{H}$, that the hybrid is necessary for class switching. Their proposed model invokes the RNA as a marker enabling a double-stranded cut at each of two sites, with end-joining finishing off the process.

\section{References}

1. Science magazine, [http://www.sciencemag.org/]

2. Immunoglobulin class switching. 